\title{
On the Fluctuation of the Kurosiwo and the Oyasiwo
}

\author{
by \\ T. Nannichi \\ Meteorological Research Institute \\ (Received December 27, 1950)
}

\begin{abstract}
Using the occupied area in the fixed section by the oceanic current, we can represent to some extent the intensity of the Kurosiwo and the Oyasiwo. In the present paper, we can see that the Kurosiwo was very strong in 1948, and it was a little warmer in 1949 than the average year, and the Kurosiwo and the Oyasiwo were both strong from spring to early summer in 1950.
\end{abstract}

\section{In îroduction}

By observing the temperature, chlorinity and other oceanograpical elements in a selected section and by representing the heat quantity carried by the curient through the section as a function of time, we can estimate the rate of fluctuation of the current and the heat exchange with the atmosphere, which will be important materials for long-range weather forecasting.

Let the $x-y$ plane be chosen on the water surface and let the current run only in the direction of $x$ with the velocity of $u$, where $z$-axis is chosen vertically downwards.

Now, consider the elementary volume $\Delta x \Delta y \Delta z$, then the rate of thermal change per unit time is given by

$$
\rho c T \Delta x \Delta y \Delta z / \Delta t
$$

where, $\rho, c, T$ and $t$ are respectively the density, specific heat, temperature and time. Needless to say, $\rho, \mathrm{c}, \mathrm{T}$ are the functions of $2, y, z, t$

As the variations of $\rho$ and $c$ are smaller than those of other quantities, they may be regarded as constants. Then, in the section $x=$ constant, we have const. $\times T(y, z, t) \times u(y, z, t) \times \Delta S(t)$.

The above quantity should be integrated over the observed area.

\section{The Selecton of the Section}

As the plane $a=$ const., the section along the so-called " $C$ " line(1) $\left(38^{\circ} 18^{\prime} \mathrm{N}\right)$ is not appropriate as a section through which both the Kurosiwo and the Oyasiwo currents cross at right angles, for there runs the polar front near by and the stream lines are very much complicated and variable. To investigate the Krosiwo, we should select a more southern section, and as to the Oyasiwo a more northern section than the "C" section would be better. However, since we can see there the fluctuation of both currents and the state in this section may have a profound effect upon the climate of the Tohoku district, we took up the " $C$ " section for investigation. 


\section{The Oceanographical State}

As in his previous paper(2), the author defines that the water of the Oyasio has less chlor inity than $18.80 \%$ and that of the Kurosiwo to have more chlorinity than $19.00 \%$. Some examples of the calculated density current in the section were reported previously ${ }^{(3)}$. This time, to observe the current velocity, the author went aboard the observation ship "Ukura maru" which departed on July 15, 1950, on her 66th voyage toward the northern fixed point $\left(39^{\circ} \mathrm{N}, 153^{\circ} \mathrm{E}\right)$ and measured (4) the current velocity

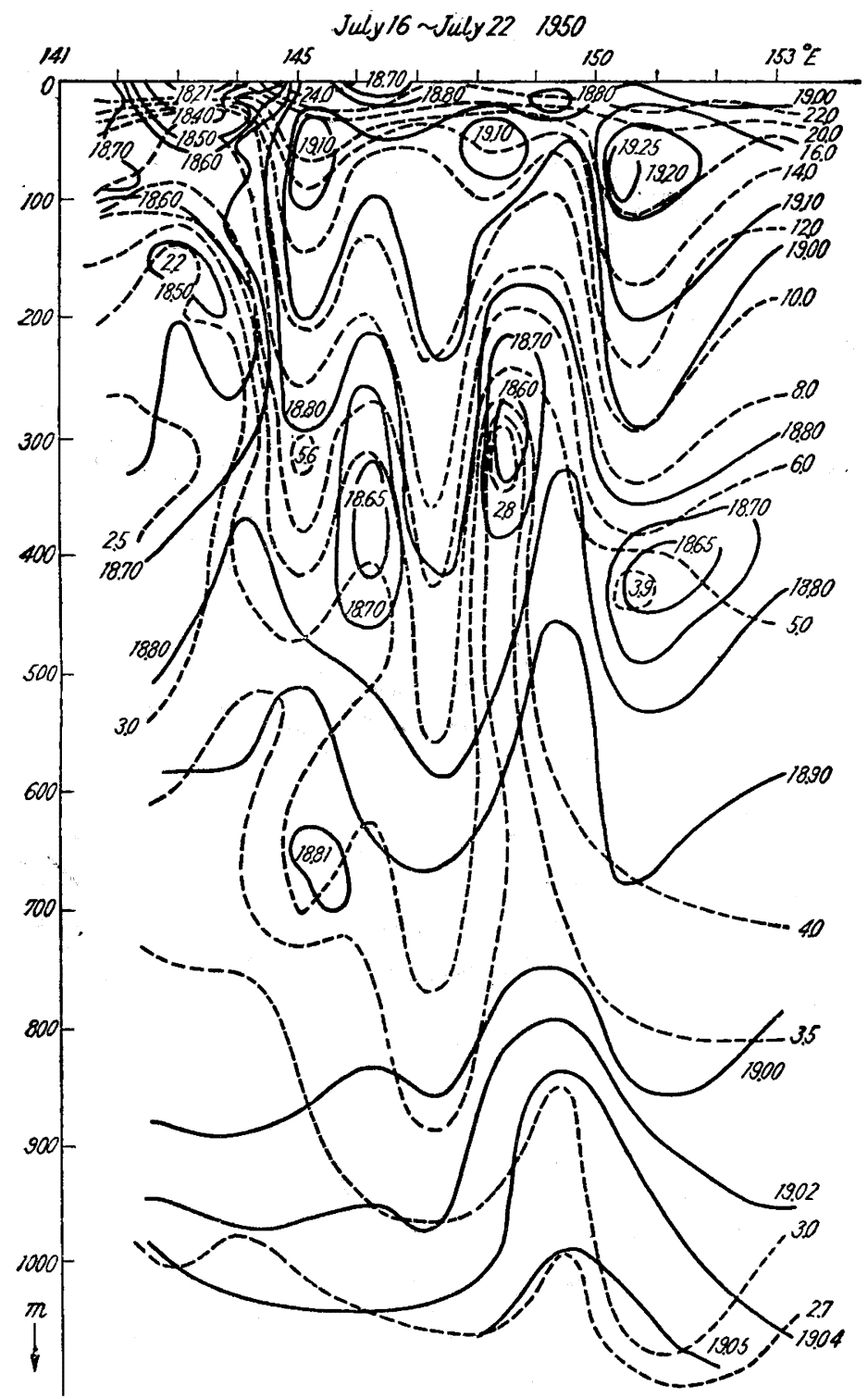

Fig. 1 Vertical distribution of temperature and chlorinity along the "C" section. Unit : ${ }^{\circ} \mathrm{C}, 0 \%$ 
with Ekman-Merz current-meters. The water temperature, chlorinity, dissolved oxygen and plankton were also observed as usual. Distribution of temperature, chlorinity and oxygen content in the section of $38^{\circ} 18^{\prime} \mathrm{N}$ are shown in Fig. 1 and Fig. 2. We can find out the water mass of the Oyasiwo with lower temperature and chlorinity in regions $142^{\circ} \mathrm{E}, 143^{\circ} \mathrm{E}, 144^{\circ} \mathrm{E}, 146^{\circ} \mathrm{E}, 148^{\circ} \mathrm{E}, 150.5^{\circ} \mathrm{E}$. When a water particle with

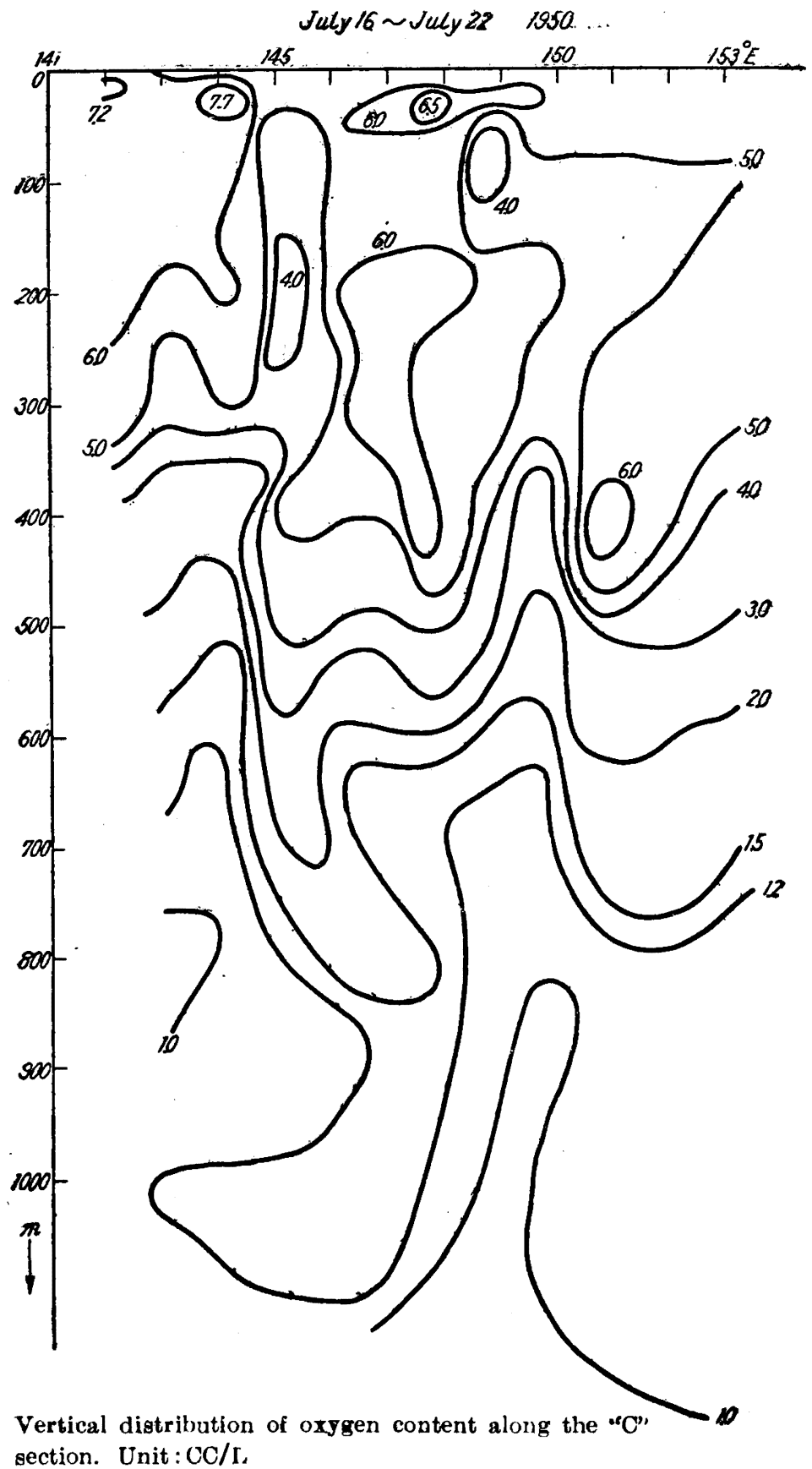

Fig. 2 Vertical distribution of oxygen content along the "C" section. Unit: $\mathrm{CC} / \mathrm{h}$, 


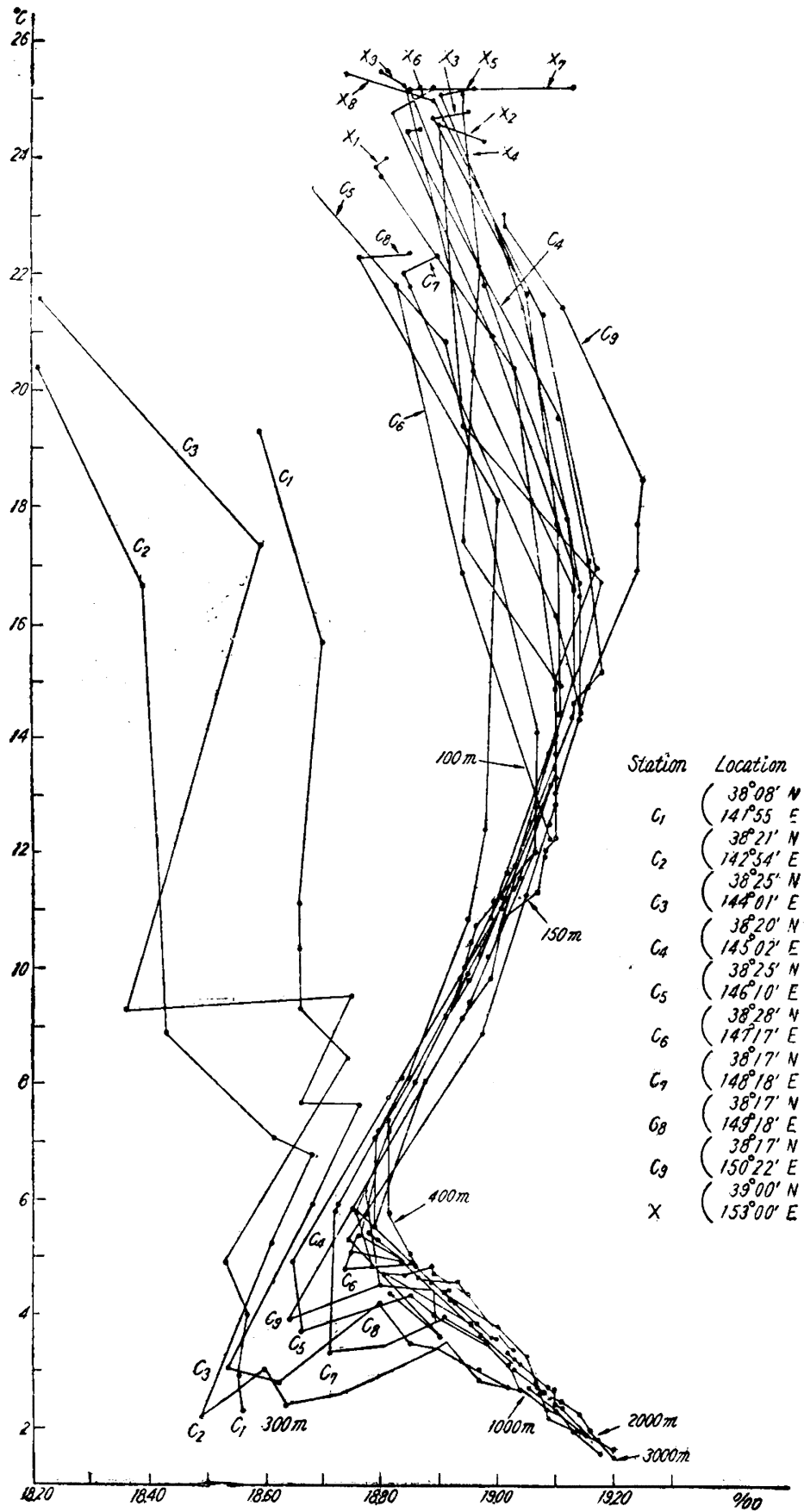

Fig. 3 T-C1 diagrain along the " $\mathrm{C}$ " section. 
Table 1

\begin{tabular}{|c|c|c|c|c|c|c|c|c|c|c|c|c|c|c|c|c|}
\hline$\overline{\overline{\text { Depth(in) }}}$ & \multirow{2}{*}{\multicolumn{2}{|c|}{\begin{tabular}{l|l|} 
\\
\end{tabular}}} & \multirow[t]{2}{*}{10} & \multirow[t]{2}{*}{25} & \multirow{2}{*}{\multicolumn{2}{|c|}{$50 \mid 75$}} & \multirow{2}{*}{\multicolumn{2}{|c|}{\begin{tabular}{l|l|l|}
100 & 150 \\
\end{tabular}}} & \multirow{2}{*}{200} & \multirow[t]{2}{*}{300} & \multirow[t]{2}{*}{400} & \multirow{2}{*}{500} & \multirow{2}{*}{600} & \multicolumn{2}{|c|}{8001000} & TVind \\
\hline Station & & & & & & & & & & & & & & 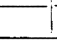 & & $(\mathrm{m} / \mathrm{s})$ \\
\hline $\mathrm{C}_{2} \sim \mathrm{C}_{1}$ & Cal. Val. $\mathrm{cm} / \mathrm{sec}$ & -1.5 & -2.5 & -3.0 & $|-2.5|-$ & -1.9 & $-1.5 \mid$ & -1.3 & -1.0 & 0 & & & 1 & & & \\
\hline $\mathrm{C}_{3} \sim \mathrm{C}_{2}$ & Cal. Val. cm/sec & 4.0 & 3.6 & $\overline{3.2}$ & 2.7 & $\overline{2.2}$ & $\overline{1.9}$ & 1.3 & 2.0 & 0.2 & & -0.2 & $-(1,2$ & $(0.2)$ & 0.2 & \\
\hline $\mathrm{C}_{3}$ & Obs. Val. & & & & & & & & & & & & & & & \\
\hline & Raw Mat & & & & & & & & & & & & & & & \\
\hline & $\mathrm{cm} / \mathrm{sec}$ & & & & & & 46.0 & & & 51.0 & & & & & & $5.2 \mathrm{~m} / \mathrm{s}$ \\
\hline & Dir ${ }^{\circ}$ & & & & & & 230 & & & 212 & & & & & & 205 \\
\hline & Corr. Val & & & & & & & & & & & & & & & \\
\hline & $\mathrm{cm} / \mathrm{sec}$ & & & & & & 9.0 & & & 0 & & & & & & \\
\hline & Dir. ${ }^{\circ}$ & & & & & & $\overline{340}$ & & & 1 & & & & & & \\
\hline $\mathrm{C}_{4} \sim \mathrm{C}_{3}$ & Cal. Val, cm $/ \mathrm{sec}$ & 4.6 & 24.0 & 22.0 & 19.21 & 16.8 & 27.2 & 11.8 & 9.7 & 7.4 & 5.3 & 4.0 & 3.3 & 0.7 & 0 & \\
\hline $\mathrm{C}_{3}$ & Obs. Val. & & & & & & & & & & & & & & & \\
\hline & Raw Mat & & & & & & & & & & & & & & & \\
\hline & $\int \mathrm{cm} / \mathrm{sec}$ & & & & $\overline{63.0}$ & & $\overline{57.3}$ & & $\overline{78.8}$ & 70.0 & & & 89.5 & & & $9.8 \mathrm{~m} / \mathrm{s}$ \\
\hline & Dir ${ }^{\circ}$ & & & & $24 y$ & & 234 & & 243 & $\overline{234}$ & & & 237 & & & 225 \\
\hline & Corr. Val. & & & & & & & & & & & & & & & \\
\hline & $\mathrm{cm} / \mathrm{sec}$ & & & & $\overline{32.0}$ & & $\overline{33.0}$ & & $\overline{15.0}$ & 20.0 & & & 0 & & & \\
\hline & Dir. ${ }^{\circ}$ & & & & 20 & & 52 & & 6 & 57 & & & 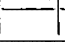 & & & \\
\hline $\mathrm{C}_{5} \sim \mathrm{C}_{4}$ & Cal. Val. cun/sec & $|-3.4|$ & -3.4 & -3.5 & -4.2 & -2.6 & -1.2 & 0.5 & 0.9 & 1.0 & 0.5 & 0.8 & $|-0.4|$ & -0.4 & 0 & \\
\hline $\mathrm{C}_{6} \sim \mathrm{C}_{5}$ & Cal. Val. $\mathrm{cm} / \mathrm{sec}$ & 9.7 & $\overline{10.5}$ & $\overline{11.6}$ & $\overline{10.5}$ & $\overline{14.5}$ & 14.4 & $\overline{14.0}$ & $\overline{13.1}$ & 10.9 & 9.3 & 6.5 & 4.3 & 1.6 & 0 & \\
\hline $\mathrm{C}_{6}$ & Obs. Val. & & & & & & & & & & & & & & & \\
\hline & Raw inat.? & & & & & & & & & & & & & & & \\
\hline & $\int \mathrm{cm} / \mathrm{sec}$ & & & & & & 206 & & & 492 & & & & & & $9 . \mathrm{ln} / \mathrm{s}$ \\
\hline & $\left\{\right.$ Dir. $^{\circ}$ & & & & & & 227 & & & 245 & & & & & & 205 \\
\hline & Corr. Val. & & & & & & & & & 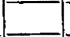 & & & & & & \\
\hline & $\mathrm{cm} / \mathrm{sec}$ & & & & & & $\overline{310^{\prime}}$ & & & 0 & & & & & & \\
\hline & Dir. $^{\circ}$ & & & & & & 67 & & & 1 & 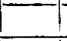 & Ho & & & & \\
\hline $\mathrm{C}_{7} \sim \mathrm{C}_{6}$ & Cal. Val. cm/sec & $-21 \cdot 0$ & $\mid-20 \cdot 6$ & $-20 \cdot 8$ & $-20 \cdot 8$ & $|-21.5|$ & $-21 \cdot 8$ & -21.3 & $-19 \cdot 6$ & -15.3 & $-11 \cdot 8$ & -8.3 & $-6.0 \mid$ & 0 & 2.3 & \\
\hline $\mathrm{C}_{8} \sim \mathrm{C}_{7}$ & Cal. Val. cm/sec & -2.2 & -3.4 & -3.7 & -4.3 & -3.5 & -2.9 & -2.1 & -1.8 & -1.4 & -0.8 & 0 & 0.5 & 0.8 & $0 . \mathrm{s}$ & \\
\hline$\overline{\mathrm{C}_{8}}$ & Obs. Val. & & & & & & & & & - & & & . & & & \\
\hline & Raw inat. & & $(15 \mathrm{~m})$ & & & & & & & & & & & & & \\
\hline & $\mathrm{cm} / \mathrm{sec}$ & & $\overline{50.5}$ & & $\overline{60.4}$ & & 62.6 & & & $\overline{49.0}$ & $\overline{48.8}$ & & & & & $8.5 \mathrm{in} / \mathrm{s}$ \\
\hline & Dir. & & 269 & & 223 & & 221 & & & 235 & $\overline{226}$ & & & & & $2 \div 5$ \\
\hline & Corr. Val. & & & & & & & & & & & & & & & \\
\hline & $\mathrm{crn} / \mathrm{sec}$ & & $\overline{40.0}$ & & 12.0 & & 15.0 & & & 8.0 & 0 & & & & & \\
\hline & Dir. $^{\circ}$ & & 327 & & 202 & & $\overline{195}$ & & & $\overline{309}$ & & & & & & \\
\hline $\mathrm{C}_{9} \sim \mathrm{C}_{8}$ & Cal. Val. $\mathrm{cm} / \mathrm{sec}$ & 36.6 & 37.3 & 36.0 & 41.1 & 41.0 & 29.4 & 36.3 & 20.5 & 24.0 & 10.1 & 7.1 & 5.1 & 2.1 & 0 & \\
\hline $\mathrm{X} \sim \mathrm{C}_{9}$ & Cal. Val. cin/sec & -5.5 & -5.7 & -5.5 & -5.4 & -5.0 & -4.2 & -3.0 & -2.2 & 1.2 & -0.6 & -0.3 & 0 & 0.3 & 0.8 & \\
\hline$\overline{\mathrm{X}_{1}}$ & Obs. Val. & & & & & & & & & & & & & & & \\
\hline & Kaw Mat & & & & & & & & & & & & & & & \\
\hline & $\int \mathrm{cm} / \mathrm{sec}$ & $\overline{50.0}$ & & & 31.5 & & $\overline{19.8}$ & & 33.8 & 97.6 & $\overline{26.0}$ & $\overline{28.5}$ & & & & $1.0 \mathrm{mn} / \mathrm{s}$ \\
\hline & Dir. ${ }^{\circ}$ & 338 & & & 188 & & 193 & & 191 & 167 & 166 & 188 & & & & 158 \\
\hline & Corr. Val. & & & & & & & & & & & & & & & \\
\hline & $\mathrm{cm} / \mathrm{sec}$ & 47.5 & & & 28.5 & & $\overline{31.5}$ & & 22.2 & 50.1 & 22.0 & 23.5 & & & & \\
\hline & Dir. & $\overline{338}$ & & & 323 & & 320 & & $\overline{298}$ & $\overline{158}$ & $\overline{340}$ & $\overline{312}$ & & & & \\
\hline $\mathrm{X}_{2}$ & Obs. Val. & & & & & & & & & & & & & & & \\
\hline & Raw. Mat. & & & & & & & & & & & & & & & \\
\hline & $\mathrm{cm} / \mathrm{sec}$ & 26.0 & & & 32.2 & & 47.0 & & & 78.1 & & & & 21.8 & & $3.4 \mathrm{~m} / \mathrm{s}$ \\
\hline & Dir. ${ }^{\circ}$ & 40 & & & 190 & & 220 & & & 255 & & & & $18 \tilde{0}$ & & 1940 \\
\hline & Corr. Val. & & & & & & & & & & & & & & & \\
\hline & $\mathrm{cm} / \mathrm{sec}$ & $\overline{20.0}$ & & & 26.0 & & 30.0 & & & $\overline{60.0}$ & & & & 20.0 & & \\
\hline & Dir. $^{\circ}$ & $\overline{53}$ & & & $\overline{143}$ & & 197 & & & 251 & & & & 119 & & \\
\hline
\end{tabular}

North-southwards current-rip was seen at the station $X_{1}, X_{2}$.

The mark(-) showing the south-going current, and the inark( + ) the north-going one 
lower temperature and chlorinity in a cold current moves into a warmer, it takes heat from the latter and becomes lighter. On the cont:ary, a warmer goes through just the opposite process. So vortices with the horizontal axes may be developed along the polar front ${ }^{(5)}$. We see the portions of divergence in the regions, $143^{\circ} \mathrm{E}, 146 .{ }^{\circ} 5$ $\mathrm{E}, 149.5^{\circ} \mathrm{E}$ and those of convergence at $145.5^{\circ} \mathrm{E}, 147.5^{\circ} \mathrm{E} .151^{\circ} \mathrm{E}$. Next, we have the $\mathrm{T}-\mathrm{Cl}$ diagram as shown in Fig. 3 . The characters of the curves at $145^{\circ} 02^{\prime} \mathrm{E}, 147^{\circ}$ $17^{\prime} \mathrm{E}, 149^{\circ} 18^{\prime} \mathrm{E}$ are quite similar to those on the fixed point where the Kurosiwo branches prevail. On the other hand, we can find water masses with lower temperature and chlorinity, namely the branches of the Oyasiwo at $141^{\circ} 55^{\prime} \mathrm{E}, 142^{\circ} 54^{\prime} \mathrm{E}$, $144^{\circ} 01^{\prime} \mathrm{E}, 146^{\circ} 10^{\prime} \mathrm{E}, 148^{\circ} 18^{\prime} \mathrm{E}, 150^{\circ} 22^{\prime} \mathrm{E}$. Among them, in the region west of $144^{\circ} 01^{\prime} \mathrm{E}$, near the coast of Sanriku, the Oyasiwo water occupies from the surface to $500 \mathrm{~m} \sim$

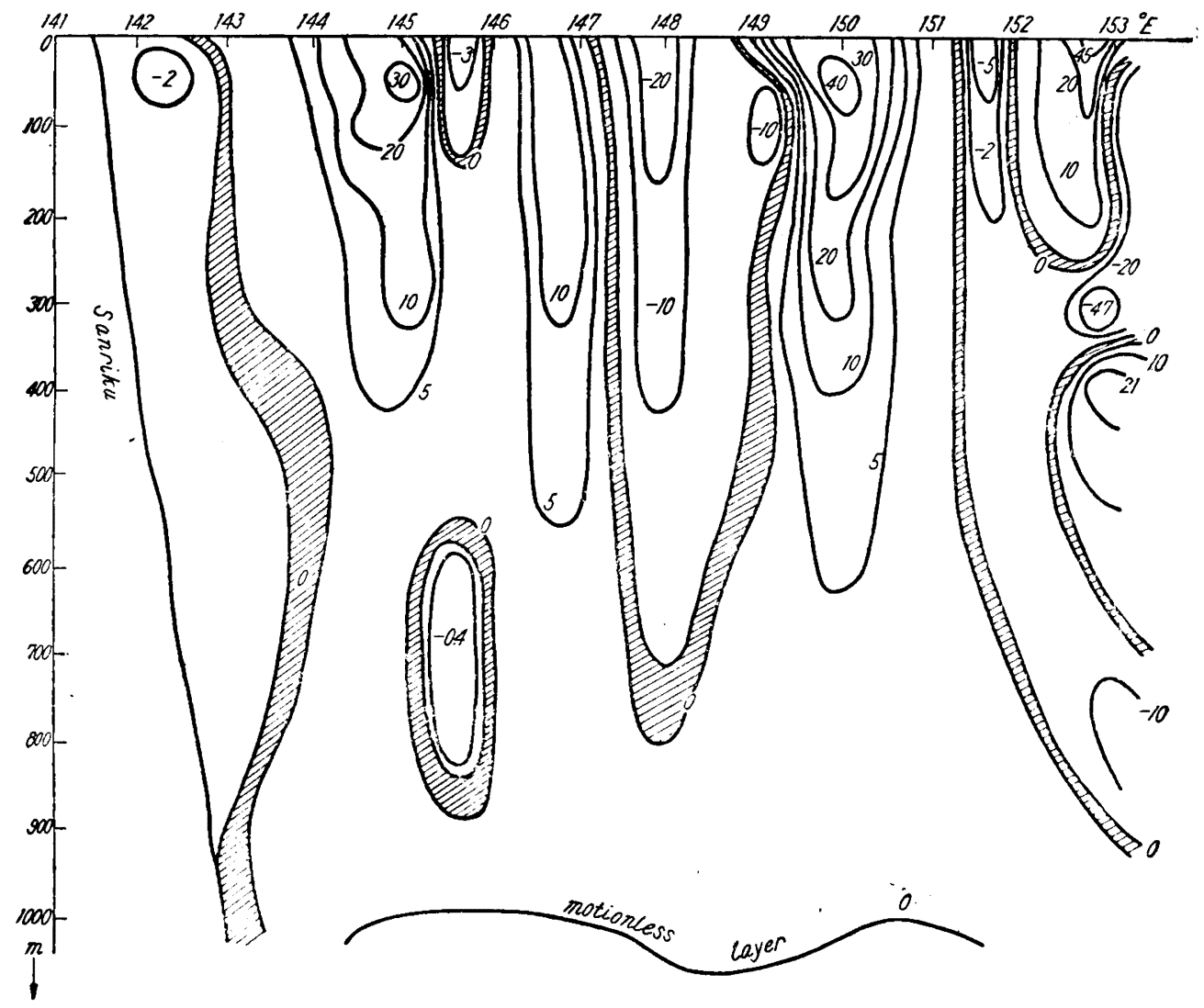

Fig. 4 Vertical distribution of $\mathrm{N}-\mathrm{S}$ component of current velocity along the "C" section. Unit: cm/sec. In the shadow part, the $\mathrm{N}-\mathrm{S}$ component of velocity is zero. 
$600 \mathrm{~m}$ layer : but east of $145^{\circ} \mathrm{E}$, the Krosiwo occupies from the surface to $200 \mathrm{~m}-$ $300 \mathrm{~m}$ layer, under which the Oyasiwo flows.

Deeper layer more than $1000 \mathrm{~m}$, the water becomes homogenous which corsists of the deep water, and the observed values are almost the same everywhere.

Using the obseryed values in Fig.1, we have calculated (6) the density current which is given in Table 1. Here, we have decided the motionless layer considering Miyazaki's method (7) and assuming that the deep water will go north slowly at the $1000 \mathrm{~m}$ layer. The observed values are also given in Table 1 which have been corrected regarding magnetic deviations. The motionless layers have been decided at reasonable depths. But, of these results two observations at the fixed point were carried out on calm days, and the velocities of the surface layer were obtained from the drift by the astronomical observations at night. It was estimated that the ship was drifted at the speed of $\mathrm{V} / 20$ knots by the wind with the speed $\mathrm{V} \mathrm{m} / \mathrm{sec}$. We collected some living matter drifting near the sea surface at the fixed point from July 25 to August 3. They were Physalia physalis, Velella lata, Porpita umbella, Siphonophora, Glaucus lineatus, Janthina Species, Cypselurus agoo. Chloeia flava, Cirripedia and Brachyura were drifting about on a glass floater of a fishing net ${ }^{(8)}$. These living matters are characteristic of the warm current ; therefore, it is sure that the Kurosiwo runs over the fixed point. We have the distribution of the North-South component of the current volocity as shown in Fig.4. Summarizing the above, we have obtained the horizontal plan in $50 \mathrm{~m}-100 \mathrm{~m}$ layer shown in Fig. 5 . As seen in the figure the signs of the velocity components of the Kurosiwo and the Oyasiwo are sometimes contrary to the usual sense, namely, the Kurosiwo flowing northward ( + ) and the Oyasiwo going southward (-). Such anomalies may be explained by the fact that line of discontinuity shows a wavy form ${ }^{(9)}$. Thus the currents are complicated and they do rot

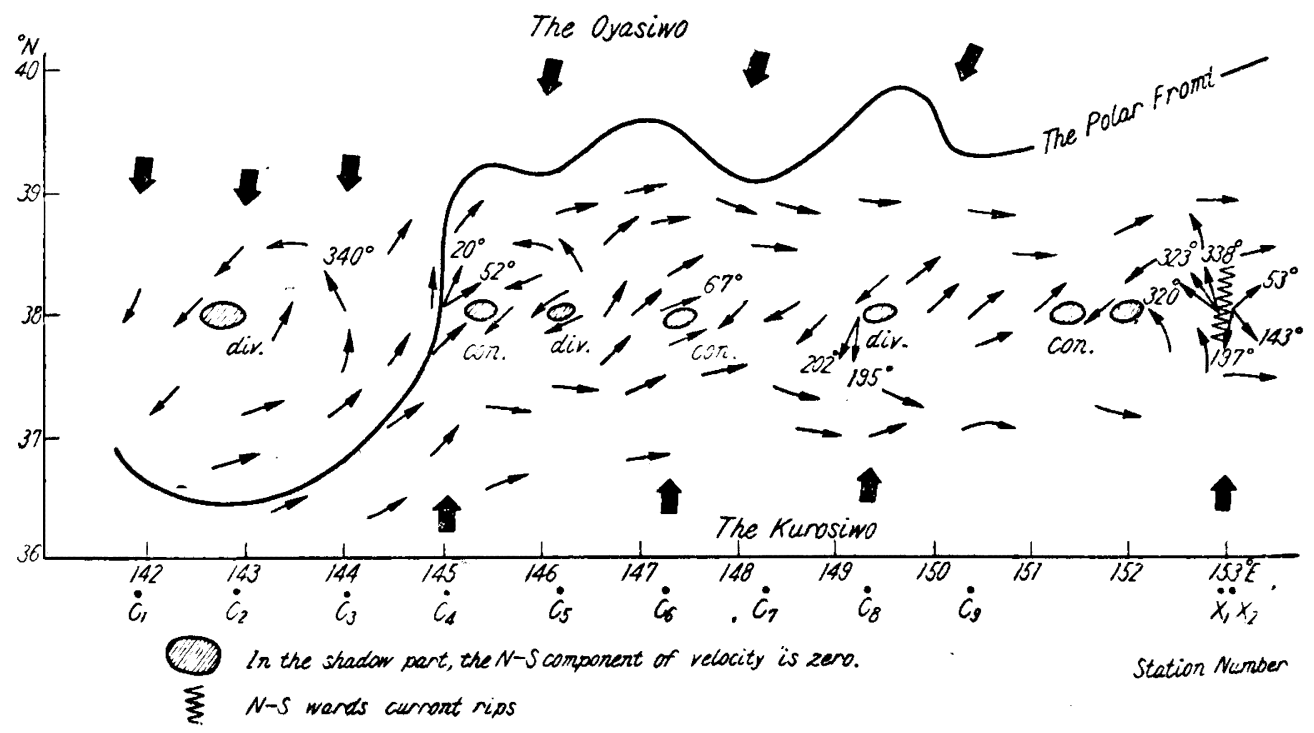

Fig. 5 Horizontal distribution of carrent at $50 \mathrm{kn} \sim 100 \mathrm{~m}$ lajer, July 1950. 
flow always in the direction of $x$-axis only, i. e. north and south, in this section. So we should take the next equation instead of the above one.

$$
\text { const. } \times\{T(y, z, t) \times \vec{u}(y, z, t) \times \Delta S(y, z, t)+T(x, z, t) \times \vec{u}(x, z, t) \times \Delta S(x, z, t)\}
$$

Next. we see that the isotherms show wary forms on the $x-y$ plane and the water temprature varies along the $z$-axis with the annual variation ${ }^{(10)}$ as follows,

$$
T=T_{0}\left(B \cos \frac{\pi}{D} y-C \Omega\right)\left\{1+\sin \frac{\pi}{12}|(t-3)|\right\} f(z), \quad t=1,2, \cdots \cdots, 12 .
$$

On the plane $x=$ const.

$$
T=T_{0}\left(B \cos \frac{\pi}{D} y-k\right)\left\{1+\sin _{12} \frac{\pi}{12}(t-3) \mid\right\} f(z)
$$

In the next place, it should be considered how much area is occupied respectively by the Kurosiwo and the Oyasiwo in the section. In the previous paper(11), the author showed the figures concerning the Kurosiwo which varied annually, and attempted the predication of the state of the Kurosiwo in the spring of 1950, but it was failed, because data available had been too scanty. The ratios of the Kurosiwo or the Oyasiwo, to the whole observed area, that is, in the case of the Kurosiwo the observed area being limited to $300 \mathrm{~m}$ depth, and in the case of the Oyasiwo to $600 \mathrm{~m}$ depth, are given in Table 2 , in which the maximum and the minimum

Table 2

\begin{tabular}{|c|c|c|c|c|c|c|c|c|c|}
\hline \multicolumn{2}{|c|}{ Voyage Date } & \multirow{2}{*}{$\begin{array}{c}\begin{array}{r}\text { Ratio } \\
\times 10^{2}\end{array} \\
13\end{array}$} & \multirow{2}{*}{$\begin{array}{l}\text { Area } \\
\times 276.68 \mathrm{kin} \\
.35 .97\end{array}$} & \multicolumn{2}{|c|}{$\begin{array}{l}\text { Teinp. }{ }^{\circ} \mathrm{C} \\
\text { min. } \max \end{array}$} & \multirow{2}{*}{$\begin{array}{c}\begin{array}{r}\text { Ratio } \\
\times 10^{2}\end{array} \\
48\end{array}$} & \multirow{2}{*}{$\begin{array}{l}\text { Area } \\
\times 540.19 \mathrm{~km}^{2} \\
259.29\end{array}$} & \multicolumn{2}{|c|}{$\begin{array}{l}\text { Ternp. }{ }^{\circ} \mathrm{C} \\
\text { min. max. }\end{array}$} \\
\hline 20 & $8-26$ & & & 10.5 & 20.0 & & & 1.9 & 24.0 \\
\hline 22 & $9-27$ & 40 & 110.67 & 8.0 & 24.0 & - & - & 2.4 & 19.7 \\
\hline 27 & $11-25$ & 19 & 52.57 & 9.5 & 17.7 & - & - & - & - \\
\hline 32 & $2-1$ & 18 & 49.80 & 8.0 & 15.0 & 38 & 205.27 & - & 10.0 \\
\hline 39 & $5-18$ & 7 & 19.37 & 11.4 & 15.5 & - & - & - & 8.9 \\
\hline 40 & $6-4$ & 38 & 105.14 & 10.4 & 16.2 & - & - & - & 13.7 \\
\hline 42 & $7-8$ & 42 & 116.21 & 10.0 & 21.5 & - & - & 2.2 & 17.0 \\
\hline 43 & $7-25$ & 31 & 85.77 & 9.0 & 24.4 & 37 & 199. 87 & 1.9 & 21.5 \\
\hline 44 & $8-11$ & 14 & 38.74 & 11.7 & 22.8 & - & - & 1. $s$ & 24.2 \\
\hline 45 & $8-30$ & 17 & 47.04 & 11.4 & 25.2 & - & 一 & 2.7 & - \\
\hline 46 & $9-15$ & 25 & 69.17 & 13.0 & 23.8 & - & - & 2.6 & - \\
\hline 47 & $8-30$ & 21 & 58.10 & 12.0 & 23.7 & - & - & - & - \\
\hline 51 & $11-26$ & 一 & - & - & - & 41 & 221.48 & 2.3 & 34.8 \\
\hline 52 & $12-11$ & 16 & 44.27 & 6.3 & 20.6 & 一 & - & 2.1 & 13.0 \\
\hline 61 & $4-20$ & 21 & 58.10 & 10.7 & 15.6 & 33 & 178. 26 & 3.5 & 7.4 \\
\hline 62 & $5-7$ & 26 & 71.94 & 6.3 & 15. 2 & 41 & 221.48 & $3 . \tilde{b}$ & 9.3 \\
\hline 63 & $5-25$ & 22 & 60.87 & 10.9 & 17.0 & 47 & 253.89 & 2.5 & 9.0 \\
\hline 64 & $6-12$ & 24 & 66.40 & 11.4 & 21.1 & 54 & 291.70 & 2.5 & 7.8 \\
\hline 65 & $6-29$ & 33 & 91.31 & 10.2 & 22.5 & 39 & 210.67 & 3.1 & 18.7 \\
\hline 66 & $7-17$ & 37 & 102.37 & 10.8 & 22.0 & 42 & 226.88 & 2.3 & 23.7 \\
\hline 67 & $8-4$ & 27 & 74.70 & 11. 2 & 23.0 & 39 & 210.67 & 1.6 & 26.7 \\
\hline
\end{tabular}

The Kurosiwo

The Oyasiwo 

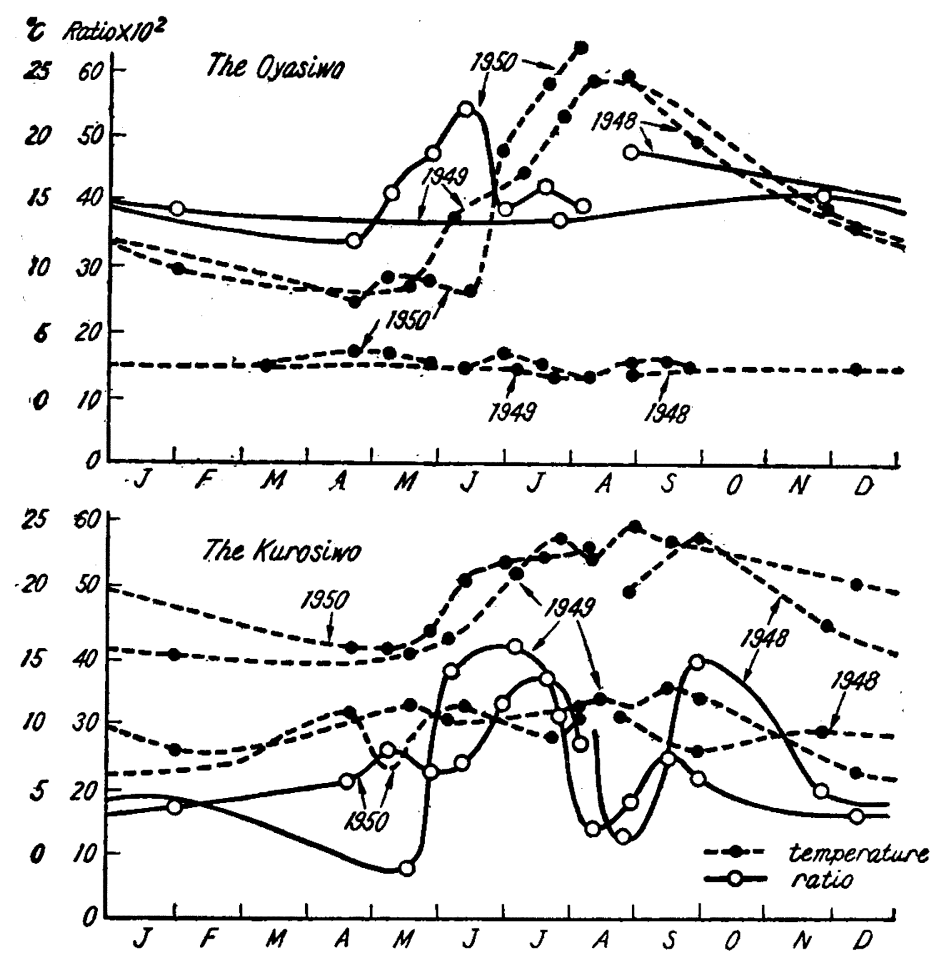

Fig. 6

temperature in the Kurosiwo and the Oyasiwo area are also given. These are also shown in Fig.6، It is difficult to have an equation of $\mathrm{S}$ as a function of x.y.z.t.Though we may graphically integrate $T \times u \times \Delta S$ in each part, over each occupied area, it is a laborious work. Then, instead of making graphical integrations, can we see to some extent the fluctuation of the currents only by knowing the change in each area?

\section{The Fluctuation of the Kurosiwo and the Oyasiwo}

We saw that the intensity of the Kurosiwo in 1949 was less than in the preceding year. If this tendency should continue, it would become still less 1950, but actually, it was stronger and warmer than the average year in April and May of 1950 contrary to our expectation. The decrease of area of the Kurosiwo in this section in August is probably due to the rainy season in the region of the sourse of the Kurosiwo in the vicinity of Formosa(12).

The ratios of the Oyasiwo during the two years were almost the same for scanty data, but it was larger from April to July, 1950, during which the Oysiwo was stronger.

\section{Acknowledgment}

The author expresses his best thanks to Dr. Y. Miyake and Dr. R. Saito for their encouragement, and to Mr.M. Koizumi, Mr.R. Marumo, Mr.M. Torii and all the other observers for their kind help. 


\section{References}

(1) T. Nannchi: On the Variation of the Oceanographical State of the so-called "C" line. Oceanographical Mag., 3 (1951) in printing

(2) ibid.

(3) ibid.

(4) The observers:T. Nannichi, M. Torii, T. Yanagata, S. Hasegawa.

(5) K.Suda: On the Dissipation of Energy in the Density Current. (2 nd Paper) Geophys. Mag. , 10 (1936) 166

(6) The calculation was carried out by Mr. M. Torii.

(7) M. Miyazaki : On the Computation of the Stationary Currents. Geophys. Mag., 15 (1948) 58

(8) The identifcation of living unatters was dene by Mr. R. Marumo.

(9) loc. cit. (1)

(10) T. Nannichi : On the Austausch Coefïicient in the Sea. Oceanographical Mag., 3 (1951) in printing

(11) T. Nannichi : loc. cit. (1)

(12) T. Nannichi : loc. cit. (1) 